\title{
Wpływ duchowości Pustelni Optyńskiej na twórczość rosyjskich filozofów i pisarzy XIX w.
}

\author{
Tomasz Kuprjanowicz \\ Chrześcijańska Akademia Teologiczna w Warszawie \\ Polska \\ t.kuprjanowicz@interia.pl
}

\begin{abstract}
Tomasz Kuprjanowicz, The Influence of the Spirituality of the Optina Monastery on the Work of Russian Philosophers and Writers of the Nineteenth Century, Elpis, 18 2016: 57-64.

Abstract: Monasteries in nineteenth century Russia had a major influence on the nation. One such example was the Monastery of the Entrance of the Mother of God into the Temple in Kozelsk, which is also known as the Optina Monastery. The pilgrims who travelled to this spiritual centre were not only common people. Russian philosophers and writers were also guests at the monastery on several occasions. The spiritual nourishment which they received from the monks influenced their creativity and life aspirations. The Elders of the Optina Monastery became for them spiritual guides and moral authorities, and even creative inspiration. The creators of Russian culture at that time, who were in contact with the Optina Monastery include, Ivan Kireyevsky, Nikolai Gogol, Fyodor Dostoevsky and Konstantin Leontyev. Personal contact with the Elders of the Optina Monastery contributed to the these philosophers' deeply spiritual views, which sustained their strength for the moral transformation not only of their own person, but also of the whole of society.
\end{abstract}

\begin{abstract}
Streszczenie: Monastery w Rosji w XIX-stym wieku miały bardzo duży wpływ na naród. Jednym z takich monasterów był właśnie wtedy Kozielski Monaster Wprowadzenia Matki Bożej do Świątyni zwany Pustelnią Optyńską. Był to taki ośrodek duchowy, do którego przybywali pielgrzymi nie tylko z prostego ludu. Częstymi gośćmi w monasterze byli rosyjscy filozofowie i pisarze. Duchowe pożywienie, jakie otrzymywali od mnichów wpływało na ich twórczość i życiowe dążenia. Starcy z Pustelni Optyńskiej stawali się dla nich duchowymi przewodnikami i moralnymi autorytetami, a nawet twórczą inspiracją. Twórcami rosyjskiej kultury tego okresu majacymi kontakt z Pustelnią Optyńską byli m.in. Iwan Kirejewski, Nikołaj Gogol, Fiodor Dostojewski i Konstantin Leontjew. Żywe kontakty ze starcami z Pustelni Optyńskiej otwierały w filozofach i pisarzach pokłady głębokiej duchowości, podtrzymujące ich siły do moralnego przeobrażenia nie tylko własnej osoby, ale i całego społeczeństwa.
\end{abstract}

Keywords: The Optina Monastery, The Elders, Kireyevsky, Gogol, Leontyev, Dostoyevsky

Słowa kluczowe: Pustelnia Optyńska, starcy, Kirejewski, Gogol, Leontjew, Dostojewski

\section{Wstęp}

Monastery w Rosji w XIX-tym wieku miały bardzo duży wpływ na naród. Dokonywał się on poprzez doświadczonych w życiu (przede wszystkim duchowym) mnichów. Ludzie zwracali się do nich szukając prawidłowej drogi życia, a oni troszczyli się o duchową stronę narodu poprzez kazania i bezpośrednią rozmowę. Przyczyniali się w ten sposób do religijno - moralnego trybu życia społeczeństwa. Z biegiem czasu monastery stały się ośrodkami życia kulturalnego. Przy monasterach otwierały się szkoły, gdzie uczono nie tylko umiejętności czytania i pisania, ale również języków obcych, zgłębiano literaturę patrystyczną i dyskutowano nad nią. Chrześcijańskie wartości moralne zakorzenione $\mathrm{w}$ narodzie i przekazywane $\mathrm{z}$ pokolenia na pokolenie przyczyniły się do intensywnego rozwoju kultury w XIX-tym wieku.

Jednym $\mathrm{z}$ takich monasterów był właśnie wtedy Kozielski Monaster Wprowadzenia Matki Bożej do Świątyni zwany Pustelnią Optyńską. Był to taki ośrodek duchowy, do którego przybywali pielgrzymi nie tylko z prostego ludu. Duża ich część była z inteligencji. Przyjeżdżali tam m. in.:
- Iwan Wasiljewicz Kirejewski (1805-1856), rosyjski filozof, krytyk literacki i publicysta, słowianofil;

- Natalija Pietrowna Kirejewska (z domu Arbjenjewa, 1809 - 1900) - żona Iwana Kirejewskiego;

- Piotr Wasiljewicz Kirejewski (1808-1856), rosyjski pisarz, tłumacz, folklorysta, archeograf;

- Nikołaj Wasiljewicz Gogol (1809-1852), rosyjski i ukraiński pisarz, prozaik, poeta, dramaturg i publicysta tworzący w języku rosyjskim;

- Wasilij Andriejewicz Żukowski (1783-1852), rosyjski poeta i pisarz, jeden z założycieli romantyzmu w poezji rosyjskiej, tłumacz dzieł literackich;

- Aleksiej Stiepanowicz Chomiakow (1804-1860), rosyjski poeta i dramaturg, malarz, pisarz, teolog, filozof oraz założyciel wczesnego słowianofilstwa;

- Iwan Sjergjejewicz Aksakow (1823-1886), rosyjski pisarz, poeta, działacz społeczny, jeden z liderów ruchu słowianofilskiego;

- Konstantin Sjerjejewicz Aksakow (1817-1860), rosyjski pisarz, poeta, krytyk literacki, historyk i językoznawca, przywódca rosyjskich słowianofilów i ideolog słowianofilstwa; 
- Fiodor Iwanowicz Tiutczew (1803-1873), rosyjski poeta i dyplomata, konserwatywny publicysta;

- Iwan Siergiejewicz Turgieniew (1818-1883), rosyjski pisarz, poeta, publicysta, dramatopisarz, tłumacz;

- Michaił Pietrowicz Pogodin (1800-1875), rosyjski historyk, pisarz, dziennikarz, profesor Uniwersytetu Moskiewskiego i członek Petersburskiej Akademii Nauk;

- Stepan Pietrowicz Shevyryov (1806-1864), rosyjski krytyk literacki, historyk, poeta, dziennikarz;

- Piotr Andrejewicz Wiaziemski (1792-1878), rosyjski książę, poeta i krytyk literacki;

- Aleksiej Konstantinowicz Tołstoj (1817-1875), rosyjski graf, pisarz, poeta i dramaturg;

- Fiodor Michajłowicz Dostojewski (1821-1881), rosyjski pisarz, myśliciel, filozof i publicysta;

- Piotr Iljicz Czajkowski (1840-1893), rosyjski kompozytor, dyrygent, pedagog, działacz społeczny w muzyce, dziennikarz muzyczny;

- Modest Iljicz Czajkowski (1850-1916), biograf i twórca librett do oper swojego brata;

- Nikołaj Grigorjewicz Rubinstein (1835-1881), rosyjski pianista i kompozytor, brat pianisty Antona Rubinsteina. Założyciel i pierwszy dyrektor konserwatorium w Moskwie;

- Aleksiej Michajłowicz Zhemchuzhnikov (1821-1908), rosyjski poeta liryczny, satyryk i humorysta;

- Tertij Iwanowicz Filipow (1826-1899), działacz polityczny i społeczny, pisarz;

- Aleksjej Nikołajewicz Apuchtin (1840-1893), poeta, krytyk literacki;

- Michaił Aleksandrowicz Maksimowicz (1804-1873), rosyjski uczony, historyk, botanik, etnograf, filolog, członek-korespondent Carskiej Akademii Nauk w Sankt Petersburgu, pierwszy rektor Kijowskiego Carskiego uniwersytetu świętego Włodzimierza;

- Andrej Nikołajewicz Murawjow (186-1874), rosyjski pisarz religijny, teolog i historyk;

- Pamfił Daniłowicz Jurkjewicz (1826-1874), rosyjski i ukraiński filozof i pedagog;

- Nikołaj Nikołajewicz Strachow (1828-1896), rosyjski filozof, publicysta, krytyk literacki;

- Wiktor Ipatjewicz Askoczenskij (1820-1879), rosyjski poeta, pisarz, dziennikarz, historyk i wydawca;

- Stjepan Onisimowicz Buraczjok (1800-1877), budowniczy statków, matematyk, pisarz, wydawca;

- Władimir Siergiejewicz Sołowjow (1853-1900), rosyjski filozof religijny, mistyk, poeta, publicysta, krytyk literacki;

- Konstantin Nikołajewicz Leontjew (1831-1891), rosyjski filozof, pisarz, lekarz i dyplomata. [zob. Благословенная 1997, online]

Rosyjscy filozofowie i pisarze byli częstymi gośćmi monasteru. Duchowe pożywienie, jakie otrzymywali od mnichów wpływało na ich twórczość i życiowe dążenia. Starcy z Pustelni Optyńskiej stawali się dla nich duchowymi przewodnikami i moralnymi autorytetami, a nawet twórczą inspiracją. W artykule postaram się przedstawić powyższy wpływ pochylając się nad wybranymi twórcami rosyjskiej kultury tego okresu.

\section{Iwan Kirejewski}

Szczególnie duży wpływ mnichów był na słowianofilów braci Kirejewskich. Swą przygodę z filozofią bracia rozpoczęli od zgłębiania panującej wówczas na Zachodzie filozofię Hegla i Schellinga. Nie znaleźli w niej jednak tej prawdy, którą dała im wiara prawosławna. Cała ich spuścizna literacka tworzona była pod wpływem starców z Optiny. Duchowym ojcem dla Iwana Kirejewskiego był starzec Makary (Iwanow). Świadczy o tym fakt, że wszystkie listy kierowane do starca podpisywał on słowami „Духовный сын" [Четвериков 1988, 119-120]. Kontakt ze starcem Makarym zrodził się po ślubie Iwana z Natalią Pietrowną z domu Arbjenjewą. Była ona duchowym dzieckiem wielkiego rosyjskiego świętego Serafina z Sarowa. Po Jego śmierci przeszła pod opiekę optyńskiego starca Makarego. Odwiedzała często monaster i kierowała się w swoim życiu duchowo - moralnymi radami mnichów z Optiny. W jej domu znajdowała się bardzo duża ilość pism Świętych Ojców. Pod jej wpływem Iwan Kirejewski stopniowo zaczął interesować się życiem Cerkwi. Po przyjeździe z zagranicy Iwan Kirejewski skoncentrował się na poznaniu chrześcijańskich dogmatów, na rozwijaniu prawosławnego życia duchowego i na tworzeniu prawosławnej filozofii. Warto tutaj zauważyć, że słowianofile dążyli do połączenia religii prawosławnej z filozofią i że właśnie Iwan Kirejewski i Aleksiej Chomiakow stali się pierwszymi rosyjskimi prawosławnymi filozofami.

Iwan Kirejewski będąc prawosławnym, ściśle związanym ze schimnikami - mnichami z Pustelni Optyńskiej usiłował bez wątpienia wpłynąć na moralność i wykształcenie społeczeństwa. Kontakty te pomogły w napisaniu artykułów, dotyczących wykształcenia w prawosławnym duchu. W 1852 roku wychodzi jego artykuł O charakterze oświecenia Europy i jego stosunek do oświecenia Rosji (О характере просвещения Европы и его отношение $\kappa$ просвещению России), w którym jest podana porównawcza charakterystyka rosyjskiego i europejskiego wykształcenia. „Западный человек искал развитием внешних средств облегчить тяжесть внутренних недостатков. Русский человек стремился внутренним возвышением над внешними потребностями избегнуть тяжести внешних нужд» [Киреевский 1984, 232].

Doprowadzić do takiej konkluzji doprowadzić mogło tylko czytanie literatury Świętych Ojców i bliska znajomość $\mathrm{z}$ duchowym życiem monasteru. Zainteresowanie oświeceniem społeczeństwa potwierdza fakt z 1854 roku, kiedy to Iwan Kirejewski napisał do ministra oświaty A. Norowa notatkę $O$ potrzebie nauczania języka cerkiewnosłowiańskiego w powiatowych szkołach (О нужде преподавания церковнославянского языка в уездных училищах). Była w niej mowa o tym, że społeczeństwo szuka oświecenia w oparciu о „коренных убеждениях веры и вековых обычаях нравственности", które nie osłabiały- 
by a umacniały religijne poglądy, przekonania i obyczaje [Киреевский 1997, 106-109].

W ostatnim dziesięcioleciu swojego życia Kirejewski wszystkie swoje wiadomości, siły i zdolności poświęcił jednemu celowi - służeniu prawdziwemu wewnętrznemu Oświeceniu oferowanemu światu przez Monaster w Optynie. Jak stwierdza Iwan Koncewicz, rosyjski cerkiewny historyk „из всех мирских лиц, перебывавших в Оптиной Пустыни, Иван Васильевич, ближе всех других подошел к ее духу и понял, как никто иной, ее значение как духовной вершины ${ }^{1} »$ [Концевич 1995, 207].

Iwan Kirejewski z początkiem 40-tych lat XIX-tego wieku zbliżył się do mnichów monasteru biorąc udział w ich wydawaniu książek jako sponsor i wydawca. Jego logiczny umysł, wszechstronne wykształcenie, znajomość filozofii pomogły nadać wydaniom jasny i dokładny sens. Udoskonalał się i wzbogacał swoją znajomość języka greckiego czytając prace Świętych Ojców w oryginale.

Iwan Kirejewski wniósł istotny wkład w sprawę rozpowszechniania duchowego wykształcenia społeczeństwa XIX-wiecznej Rosji. Bliski kontakt ze starcem Makarym (Iwanowym) wyraźnie określił sposób jego myślenia i życia jako głęboko wierzącego człowieka. W starcu filozof znalazł harmonię ludzkiej osobowości, która powstawała na fundamencie wspólnego działania sił umysłu i ducha walczącego z pokusami oraz doświadczenia życiowej drogi pełnej wewnętrznego ascetyzmu i wiary.

Ksiądz Gieorgii Florowskij rosyjski teolog i historyk zauważył, że Iwan Wasiljewicz do współczesnej jemu rosyjskiej teologii „относился сдержанно”, ale przy tym dla niego „характерно было сочетание внутренней свободы с самым строгим послушанием”, swoje „собственные богословские и философские занятия он вполне подчинил старческому суду старца Макария Оптинского „ [Флоровский 1991, 259].

Po śmierci Iwan Kirejewski, a także jego brat i żona byli pochowani w pobliżu głównej cerkwi monasteru. Iwan Kirejewski prowadził życie filozofa - samotnika, który przeszedł mniszą szkołę milczenia i tworząc swój światopogląd konsultował swoje pomysły z duchowym kierownikiem opierając go na nauce wiary Chrześcijańskiej. Pozostał pisarzem i współpracownikiem Rosyjskiej Cerkwi Prawosławnej w dziele szerzenia oświaty, kultury i moralności. Charakterystyczne dla niego było połączenie wewnętrznej wolności z wypełnieniem prawosławnych przykazań.

Iwan Kirejewski jako krzewiciel oświecenia i religijny filozof wpłynął na swoich przyjaciół, wybitnych pisarzy takich jak Gogol, Aksakow, Chomiakow i innych, a za ich pośrednictwem na większą część wykształconego rosyjskiego społeczeństwa.

\footnotetext{
Nazywając Pustelnię Optyńską „духовной вершиной», Koncewicz wyjaśnił co oznacza dla niego to pojęcie: w Optinie „сошлись и высший духовный подвиг внутреннего делания, венчаемый изобилием благодати даров стяжания Святого Духа, и одновременно служение миру во всей полноте, как в его духовных, так и житейских нуждах» [Концевич 1995, 207].
}

\section{Nikołaj Gogol}

Wyżej wymieniony Nikołaj Gogol był jednym z tych pisarzy, który także znalazł duchową opiekę u schimników - monachów monasteru Optyńskiego. Był to głęboko religijny pisarz, który żył życiem prawdziwego chrześcijanina. Dużo podróżował, zjeździł prawie całą Europę i odbył pielgrzymkę do Jerozolimy. Bywał w rosyjskich monasterach m. in. w Troickoj Siergiejewoj Ławrze i w Pustelni Optyńskiej. W 1847 roku pisarz pisał: „Нам, во всяком случае, следует искать тех знакомств и встреч, от которых хотя скольконибудь хорошеет душа. Сами мы не можем дойти ни к чему без помощи других. И к Богу мы можем доходить только посредством частых обращений с людьми, тоже к нему стремящихся» [Гоголь 2009, 408].

W 40-tych latach Nikołaj Gogol bardzo mocno pochyla się nad twórczością Świętych Ojców Cerkwi i duchownych pisarzy. Zakłada specjalny zeszyt, w którym zapisuje myśli, które wywarły na nim szczególne wrażenie. Ulubionym utworem pisarza stała się Drabina (Лествиц, ś) świętego Jana Klimaka. Pod wpływem dzieł patrystycznych zaczyna pisać najważniejsze swe duchowe dzieło, które nie zostało ukończone - Rozważania o Boskiej Liturgii (Размылиление о Божественной Литургии).

Przyjaciele niepokoili się o jego duchowy i fizyczny stan zdrowia. Nieodzownym było dla niego podtrzymanie nie tylko przez przyjaciól, ale i przez osoby duchowne. Postanawia dlatego jechać do Pustelni Optyńskiej. Zapewne już wcześniej Nikołaj Gogol dużo słyszał o niej i o jej starcach od swego dobrego znajomego Iwana Kirejewskiego. 17 czerwca 1850 roku Nikołaj Gogol udaje się tam razem z pisarzem i etnografem M. Maksimowiczem. Poznaje ihumena Mojżesza (Putiłowa) i hieromonacha Makarego (Iwanowa). Wywarli oni na pisarzu ogromne wrażenie. Później napisze do swojego przyjaciela hrabiego A. P. Tołstoja: „Я заезжал по дороге в Оптинскую Пустынь и навсегда унес о ней воспоминание. Я думаю, на самой Афонской горе не лучше... Я нигде не видел таких монахов. С каждым из них, мне казалось, беседует все небесное. Я не расспрашивал, кто из них как живет: их лица сказывали сами все» [Воропаев 2002, 56]. Optyński ojciec Porfiriusz (Grigorow) zapoznał pisarza z monasterem i jego historią. Gogol odwiedził także sławną bibliotekę w skicie, znaną ze swoich nadzwyczajnych, starożytnych rękopisów. Z głęboką czcią zapoznał się z jednym z najsłynniejszych z nich bułgarskim tłumaczeniem osiemdziesięciu postnych słów św. Izaaka Syryjczyka.

W 1851 roku na marginesie I tomu Martwych dusz (Мертвых душ) (egzemplarza, który należał do hrabiego A. P. Tołstoja) Gogol zostawił notatkę świadczącą o ogromnym wrażeniu, jakie wywarła na niego twórczość wielebnego Izaaka Syryjczyka: „... Жалею, что поздно узнал книгу Исаака Сирина, великого душеведца и прозорливого инока. Здравая психология и не кривое, а прямое понимание души встречаем лишь у подвижников-отшельников. Человеку, сидящему по 
уши в житейской тине, не дано понимание природы души» [Каширина 2013, 68].

Nie tylko biblioteka zrobiła na pisarzu wielkie wrażenie. $\mathrm{Z}$ zainteresowaniem obejrzał gospodarskie zabudowania, pasiekę, zgłębił wszystkie detale, drobiazgi monasterskiego życia. Jeśli ziemiański, urzędniczy sposób życia był znany Gogolowi, to monasterskiego zupełnie nie znał. Wszędzie stałym przewodnikiem pisarza był ojciec Porfiriusz (Grigorow). Gogol był zafascynowany mnichem, jego zawsze równym, spokojnym stanem ducha, pokorą, dobrocią i wyrozumiałością dla słabości i wad innych osób. To spotkanie zmieniło poglądy Nikołaja Gogola o żyjących w stanie mniszym.

Po odwiedzeniu monasteru Gogol udaje się do posiadłości Kirejewskich Dołbino, skąd pisze list do hieromonacha Filareta, w którym widać stosunek pisarza do Pustelni Optyńskiej: „Путь мой труден, дело мое такого рода, что без ежеминутной, без ежечасной помощи Божьей не может двинуться мое перо, и силы мои не только ничтожны, но их и нет без освежения свыше. Мне нужно ежеминутно, говорю вам, быть мыслями выше житейского дрязгу, и на всяком месте своего странствования быть в Оптиной Пустыни» [Котельников 2002, 270].

Po raz drugi Nikołaj Gogol przyjechał do monasteru po ukończeniu swojego poematu "Martwe dusze" w czerwcu 1851 roku. Wiadomo o tym z notatki z 2 czerwca 1851 roku umieszczonej w dzienniku hieromonacha monasteru Jefimija (Trunowa) [Нилус, online]. Podczas tego przyjazdu rozmawiał on ze starcami, a po przyjeździe do Moskwy pisze listy do ihumena Mojżesza (Putiłowa) i starca Makarego (Iwanowa), w których dziękuje za gościnność i prosi o modlitwy.

W komedii Rewizor (Ревизор) i poemacie Martwe dusze Gogol postawił społeczeństwo twarzą w twarz z jego wadami. Chciał zmusić je do szczerego zderzenia z niedoskonałościami Rosji. Nikołaj Gogol uważał za swój pisarski obowiązek poprawę moralności społeczeństwa, w tym poprzez krytyczny śmiech. Był to śmiech przez łzy. Niestety wrażenie, na które pisarz liczył nie udało się osiągnąć. Rozczarowany zamilkł. Wpadł w depresję zwracając się do religii jak do zbawienia.

Monaster Optyński dał pisarzowi odpoczynek dla duszy i przywrócił równowagę. W monasterze zetknął się z chrześcijańską doskonałością mnichów. W starcach odnalazł niezmienny spokój ducha, miłość i dobroć do ludzi, umiejętność bycia otwartymi i wesołymi. A co najważniejsze umiejętność zwalczania w sobie dręczących wątpliwości, było zbawienne dla udręczonej duszy pisarza.

Nic więc dziwnego, że myśl o przyjęciu stanu mniszego przychodziła pisarzowi do głowy. Podczas ostatnich odwiedzin Pustelni Optyńskiej 24 września 1851 roku w rozmowie ze schimnikiem - monachem Makarym (Iwanowym) poruszył ten wątek. Życie mnicha nie jest jednak spokojne. To ciągła walka. Prawdopodobnie dlatego starzec nie błogosławił pisarzowi na mniszą drogę, pozostawiając mu służbę w świecie - literackie prace tak potrzebne społeczeństwu.
Ostatnią książką Nikołaja Gogola rozpoczętą w 1845 roku była wspomniana Rozważania o Boskiej Liturgii, która została niedokończona i za życia pisarza nie była wydana. Za pomocą tej książki Nikołaj Gogol zamierzał zapoznać ludzi z cerkiewnymi nabożeństwami i ich znaczeniem, z porządkiem i sensem Liturgii. Z notatek pisarza wyraźnie widać, że zgłębił tekst nabożeństwa Liturgii Świętych Bazylego Wielkiego i Jana Złotoustego z porządkiem ich sprawowania. Nauczył się greckiego języka, żeby czytać te Liturgie w oryginale. Mnisi z Optiny dostrzegli ten utwór „запечатленным цельностию духа и особенным лирическим взглядом на предмет» [Гоголь 2001, 518].

\section{Konstanty Leontjew}

Głębiej niż inni filozofowie i pisarze - przedstawiciele kultury - zrozumiał naukę starców Konstanty Nikołajewicz Leontjew, który przyjął w Pustelni Optyńskiej postrzyżyny w mnicha przyjmując imię Klimenta. Jego osobowość była złożona, to był jeden z oryginalnych myślicieli - pisarz, polityk, mnich, żarliwy patriota Rosji, bardziej słowianofil niż człowiek zachodu, chociaż żył przez pewien czas za granicą (Turcja, Grecja, Wschód) i wchłonął w siebie zachodnią, wschodnią i rosyjską kulturę.

O swoim przyjściu do prawosławia Leontjew pisał $\mathrm{w}$ artykule List K. Leontjewa o wierze, modlitwie, słabościach duchowieństwa i samym sobie (Письмо К. Леонтьева о вере, молитве, немощах духовенства и о самом себе) „Писано по благословению Оптинского старца о.Амвросия. Март 1888 года, Оптина Пустынь»: „В 69 году ... удар следовал за ударом. Я впервые ясно почувствовал над собою какую-то высшую десницу и захотел этой деснице подчиниться, и в ней найти опору в жесточайшей внутренней буре. Я поехал на Афон, чтобы стать настоящим православным; чтобы меня строгие монахи научили веровать» [Леонтьев 1914, online].

Leontjew, kiedy znajdował się na łożu śmierci obiecał złożyć śluby mnisze. W 1871-1872 żył na Atosie, i Atoscy mnisi dali mu list do o. Ambrożego (Grenkowa). W 1873 roku archimandryta Leonid (Kawjelin), będąc w tym czasie duchowym dzieckiem mnichów Pustelni Optyńskiej, doradził mu jechać do Kozielskiego męskiego monasteru. Po raz pierwszy pisarz pojechał do monasteru w sierpniu 1874 roku i przebywał tam do 4 września. W monasterze spotkał się ze starcem Ambrożym (Grenkowym), wyspowiadał się u niego i otrzymał rady, co do przyszłego życia. Ponownie przyjechał Leontjew do Pustelni Optyńskiej w sierpniu 1875 roku.

Wiosną 1878 roku spadł na Leontjewa cios, gdyż 30 kwietnia zmarł na zapalenie płuc w Pustelni Optyńskiej hieromonach Kliment (Konstantin Karłowicz Zjedergolm), człowiek, z którym pisarza wiązała przyjaźń i duchowe pokrewieństwo. W 1882 roku wyszła książka pisarza Ojciec Kliment Zjedergolm, hieromonach Pustelni Optyńskiej (Отеи, Климент Зедергольм, иеромонах Оптиной Пустьıни), w której Leontjew nie tylko stworzył obraz swo- 
jego opiekuna i przyjaciela, ale również opisał byt i życie mnichów, ich codzienne duchowe wchodzenie w prawdę prawosławia. Przed czytelnikiem ukazuje się nie kanoniczny obraz ascety i nie dorobkiewicza, ale obraz człowieka ze wszystkimi jego niedostatkami i przeżyciami.

W Pustelni Optyńskiej pisarz przebywał od zimy 1879 do maja i jesienią 1880 roku, zajmując się pracami literackimi i duchowym doskonaleniem się. Wpływ monasterskiej duchowości na jego twórczość i życiową drogę nie podlega wątpliwości.

Wiosną 1886 roku chorego pisarza przywozi do monasteru T. I. Filippow. Leontjew postanawia urządzić się w monasterze, tak jak sobie życzył, znajdować się pod stałą duchową opieką jeroschimonacha Ambrożego (Grienkowa). W liście z 8 maja 1891 roku zaprasza do przyjazdu do monasteru: „Отчего бы и вам не приехать сюда в июне или июле? Я не знаю еще человека (а тем более из молодых, нового стиля), который не вынес бы от свидания с отц. Амвросием таких особого рода впечатлений, которые усиливают личную веру и располагают к заботе о личном спасении» [Переписка, online]. Obcując często ze starcem, Leontjew krytykuje obraz starca Zosimy w powieści Bracia Karamazow (Братья Карамазовы): „У от. Амвросия прежде всего строго церковная мистика и уже потом - прикладная мораль. У от. Зосимы (устами которого говорит сам Фед. Мих.!) - прежде всего мораль, «любовь», «любовь» и т. д., ну, а мистика очень слаба» [Переписка, online]. Te wiersze są ważne, jako świadectwo człowieka dobrze znającego jeroschimonacha Ambrożego. Nie zdążywszy napisać „Życia” starca Ambrożego, K. N. Leontjew pozostawił wspomnienia o nim w liście do W. W. Rozanowa z 14 sierpnia 1891 roku: „О. Амвросий по натуре и по уму склада более практического, чем созерцательного... И любовь, и жестокие угрозы, и высшие идеалы отречения, и снисхождение к кающимся грешникам. Прибавлю еще: он, скорее, весел и шутлив, чем угрюм и серьезен, - весьма тверд и строг иногда, но чрезвычайно благотворителен, жалостлив и добр... эпоху и людей он понимает превосходно и психологический опыт его изумительный» [Переписка, online].

W 1890 roku Pustelnię Optyńską odwiedził Lew Tołstoj, który spotkał się z K.N. Leontjewem. Pisarze dwie godziny sprzeczali się na temat wiary. K.N. Leontjew lubił L.N. Tołstoja jako genialnego pisarza i człowieka, ale nie zgadzał się z jego poglądami na religię. Po spotkaniu z K.N. Leontjewym Lew Tołstoj zapisał: „Был у Леонтьева. Прекрасно беседовали. Он сказал: „Вы безнадежны”. Это выражает вполне наше отношение в вере» [Толстой 1952, 23]. Wysoką ocenę twórczości i osobowości K.N. Leontjewa daje S.N. Bułgakow w swoim artykule Zwycięzca - pokonany (Победитель - побежденныци): „Почти суеверное удивление возбуждает сила его ума. Словно железными зубами впивается его мысль в предмет, размельчает его и проглатывает» [Булгаков 1993, 547]. Leontjew był dumny ze swojego chłonnego umysłu, ale trudniejszym i bardziej skomplikowanym było dla niego zwyciężyć pychę swojego podejścia do religii, żeby nie kolidowało to z nauką Cerkwi. Chrześcijaństwo było dla niego według sformułowania protoijereja G. Fłorowskiego „якорем личного спасения”, w którym widział „религию конца" [Флоровский 1991, 304]. Nie zauważał w nim dobrej nowiny o miłości i wiecznym życiu ducha. K.N. Leontjew odchodził od życia świeckiego zagłębiając się w religię, w Cerkiew, poza którą nie wyobrażał sobie zbawienia osobistego i powszechnego. Jego bardziej cenili i rozumieli prawosławni hierarchowie. „Оптинские старцы одобряли К. Леонтьева более, чем славянофилов, Гоголя, Достоевского, Вл. Соловьёва и считали его духовное устроение истинно православным», - pisał N. A. Bierdjajew [Бердяев 1926, online].

23 sierpnia 1891 roku w Skicie pod wezwaniem św. Jana Chrzciciela w kielii mnicha Warsonofiusza (Plechankowa) K. N. Leontjew przyjął potajemnie postrzyżyny $\mathrm{z}$ imieniem Klimenta. Po tym za radą starca Ambrożego przechodzi do Troice-Siergiejewskoj Ławry. 10 października w Szamordino zmarł jeroschimonach Ambroży (Grjenkow). K. N. Leontjew przeżywał stratę swojego duchowego przewodnika, i pisał do A. A. Aleksandrowa w liście z dnia 17 października 1891 roku: „Весть о кончине отца Амвросия не застала меня врасплох: я давно уже приучил мою мысль к этой утрате. Разумеется, ни один духовник уже не может мне заменить его» [Долгов 1997, 281].

W artykule Dobre wieści (Добрые вести) K.N. Leontjew napisał o znaczeniu monasterów: „...наш сложный, спешный образ жизни в мирском обществе мало благоприятствует сосредоточению мыслей на духовных вопросах, и с этой-то стороны монастыри и полезны, как такие центры, в которых это собирание мыслей воедино и поднятие их до нужной высоты и бесплотности достигается несравненно легче, чем в миру" [Леонтьев, online]. Stan mniszy dla K. N. Leontjewa to wyższy ideał chrześcijaństwa.

Niezrozumiały przez współczesnych, w swoich mrocznych przepowiedniach o późniejszych losach Rosji, talent K. N. Leontjewa okrzepł dzięki duchowemu wsparciu jeroschimonacha Ambrożego, hieromonacha Klimenta (Zjedergolma) i wniknięciu w sedno prawosławnych prawd. $\mathrm{W}$ okresie przebywania $\mathrm{w}$ monasterze $\mathrm{w}$ ostatnich latach wydał on następujące dzieła: Notatki pustelnika (3anucкu отшельника), Władimir Sołowjow przeciwko Danilewskiети (Владимир Соловьев против Данилевского), Plemienna polityka jako narzędzie światowej rewolисјі (Племенная политика как орудие всемирной революиии), Owoce narodowych utworów na prawosławnym Wschodzie (Плодь наииональных произведений на православном Востоке), Listy do Władimira Siergiejewicza Sołowiowa (Письма к Владимиру Сергеевичу Соловьеву), oraz krytyczne artykuły i listy, jak i autobiografię Mój literacki los (Моя титературная судьба). Prawosławne duchowno-moralne dążenie znanego rosyjskiego pisarza potwierdzają słowa z listu: „Ничего не чувствую (курсивы везде его), кроме глубокой боязни за Православную Церковь \{земную, конечно) и за Россию!» [Говоруха-Отрок, online]. 


\section{Fiodor Dostojewski}

Innym rosyjskim pisarzem, którego dzieła przeniknięte zostały chrześcijańsko - prawosławnym odczuwaniem świata był Fiodor Michajłowicz Dostojewski. Bywał on w Pustelni Optyńskiej latem 1878 roku. Jeszcze nim tu przyjechał o Pustelni Optyńskiej i jej schimnikach-monachach mógł słyszeć od N. N. Strachowa. Być może zainteresował się monasterem, kiedy był w gościnie u znajomego N. S. Kaszkina, którego posiadłość była niedaleko od monasteru.

W 1878 roku F. M. Dostojewskiemu zmarł trzyletni syn Aleksy. Pisarz przyjechał do przyjaciela i chodził pieszo do monasteru. W Optinie był trzy dni - od 25 do 27 czerwca, przyjechał, żeby uciszyć ból serca. Syn pisarza zmarł podczas ataku epilepsji i F. M. Dostojewski cierpiał, uważając siebie winnym śmierci syna. W Optinie pisarz widział miejsce pocieszenia dla swojej cierpiącej duszy, a w starcach znalazł tych, którzy rozumieli jego nieszczęście. Oprócz tego spotkanie z hieromonachem Ambrożym i obserwacja duchowego życia monasteru wpłynęła na twórcze plany pisarza, wydaje on powieść Bracia Karamazow. Obraz konkretnego mnicha był odtworzony F. M. Dostojewskim w bohaterze powieści Bracia Karamazow w starcu Zosimie. Kozielsk i Optyński monaster były odzwierciedlone w miejscu akcji jego ostatniej powieści. Głównego bohatera, który szuka duchowo-moralnych zasad życia w monasterze nazywają tak samo jak i syna F.M. Dostojewskiego, Aleksy.

W. A. Kotelnikow zauważa, że w bibliotece F. M. Dostojewskiego były szczegółowe prace z historii monasteru: Żywot optyńskiego starca hieromonacha Leonida (Жизнеописание оптинского стариа иеромонаха Леонида), Historyczny opis Kozielskiej Pustelni Optyńskiej pod wezwaniem Wprowadzenia Matki Bożej do Świątyni (Историческое описание Козельской Введенской Оптиной Пустыни). Jest to wykaz książek, które prawdopodobnie mogły być podarowane Dostojewskiemu w Optinie. Badaczka Budanowa N. [Буданова 2005, online] pisze, że wykaz ten został sporządzony na podstawie wglądu do spisów książek w bibliotece Dostojewskiego skompletowanych przez A.G. Dostojewską, a także uzupełniających bibliograficznych poszukiwań:

1. Komentarz do 6-go psalmu świętego Anastasija Sinaita (Беседа на 6- й псалом святаго Анастасия Синаита) / Wydanie Kozielskiej Pustelni Optyńskiej pod wezwaniem Ofiarowania NMP. M.: Uniw. druk. (Katkow i Ko), 1870. $32 \mathrm{s.}$

2. Z książki Wybrane kłosy pożywieniem dla duszy. Z tłumaczeń świętych Ojców Paisjusza Wieliczkowskiego (И3 книги Восторгнутые классы в пищу души. Из переводов св. Отцев Паисия Величковского) / Wydanie Kozielskiej Pustelni Optyńskiej pod wezwaniem Ofiarowania NMP. M.: Drukarnia A. Gatcuka, 1876. 28 s.

3. [Jan Maksimowicz, arcybiskup] Królewska droga Krzyża Pańskiego wprowadzajaca w życie wieczne (Царский путь Креста Господня, вводящий в жизнь вечную): W rosyjskim tłumaczeniu / Wydanie Kozielskiej Pustelni Optyńskiej pod wezwaniem Ofiarowania NMP. M., 1878. $281 \mathrm{~s}$.
Tłumaczenia książki Królewska droga Krzyża Pańskiego na język rosyjski dokonał hieromonach Pustelni Optyńskiej o. Kliment Zjedergolmem. Wszystko to potwierdza duchową więź F.M. Dostojewskiego z Optiną i to, że w swoich utworach dążył do historycznej dokładności, a $\mathrm{w}$ życiu kierował się zasadami prawosławnego chrześcijanina. Najwięcej o jego podróży pisze we Wspomnieniach (Воспоминания) A. G. Dostojewska, żona pisarza: „Вернулся Федор Михайлович из Оптиной Пустыни ... умиротворенный и значительно успокоившийся... С знаменитым „старцем” о. Амвросием Федор Михайлович виделся два раза наедине, вынес из его бесед глубокое и проникновенное впечатление... Из рассказов Федора Михайловича видно было, каким глубоким сердцеведом и провидцем был этот уважаемый „старец"'. [Достоевская 1971, 323].

Umiejętność orientowania się $\mathrm{w}$ psychice przychodzących po duchowe nastawienie ludzi, wnikania w głąb ludzkiej duszy poraziły pisarza, który poświęcił opowiadaniu o przewidywaniu przyszłości schimnika-mnicha całe strony powieści Bracia Karamazow, książka ta ukazała się drukiem w 1879 roku. On tak „много принял в душу свою откровений, сокрушений, сознаний, - pisał F. M. Dostojewski o starcu Zosimie, którego pierwowzorem był prawosławny święty Tichon Zadoński i starzec Ambroży Optyński, - что под конец приобрел прозорливость уже столь тонкую, что с первого взгляда на лицо незнакомого, приходившего к нему, мог угадывать: с чем тот пришел, чего тому нужно, и даже какого рода мучение терзает его совесть, и удивлял, смущал и почти пугал иногда пришедшего таким знанием тайны его, прежде чем тот молвил слово» [Достоевский, online (page 6)].

Z książki Żywot optyńskiego starca hieromonacha Leonida pochodzą, jak zauważyli uczeni, niektóre ważne wątki i ideowe motywy powieści Bracia Karamazow. Książka dała Dostojewskiemu cenny materiał dla przedstawienia tak zwanego „Ферапонтова монашества”. Przypomnijmy, że „великий молчальник и необычайный постник” mnich Ferapont, który wrogo odnosił się do starców, przedstawiony jest w powieści Bracia Karamazow jako gorliwy zwolennik czysto zewnętrznej, obrzędowej pobożności. Jest on przepełniony pychą i wyniosłością, ale w odróżnieniu od starca Zosimy pozbawiony pokory i miłości. „Отделяя Зосиму от Ферапонта, - pisze S.I. Fudel, - Достоевский не выдумывал... а только нашел, где припасть устами к его древнему и вечно живому источнику. Это „где” был русский монастырь Калужской епархии» [Фудель, online].

W swoich utworach F.M. Dostojewski konsekwentnie przeprowadza ideę „stanu mniszego» w świecie. Mnich $\mathrm{w}$ społeczeństwie jawi się przewodnikiem $\mathrm{z}$ języka duchowego na język duszy, misjonarzem nie tylko słowa, ale i przykładem całego swojego życia. W powieści dokładnie sprawdza się tak często podnoszony temat w twórczości pisarza, temat służenia ludzkiemu cierpieniu i nieszczęściom braterską miłością. Rosyjscy literaci pisali o wiecznych moralnych wartościach zawartych w ewangelicznym kazaniu. W pierwszym rzędzie należy zauważyć to u F. M. Dostojew- 
skiego. Nie tylko dlatego, że moralne kazanie o chrześcijaństwie w jego utworach było słyszane i przyjęte przez rosyjską inteligencję, ale i dlatego, że kazanie poruszyło tematy, których aktualność nie tylko nie zmniejsza się, a przeciwnie wzrasta z każdym następnym pokoleniem.

W monasterze tak jak i w każdym innym zgromadzeniu jest i narzekanie, i wrogość, i zawiść. Obraz bohatera powieści F.M. Dostojewskiego Bracia Karamazow ojca Feraponta, wroga starca Zosimy jawi się jaskrawą postacią, która jest przykładem fałszywej świętości. Ten opis jest historyczny: niektórzy mieszkańcy Skitu pod wezwaniem św. Jana Chrzciciela negatywnie odnosili się do schimonacha Leonida (Nagołkina), do pielgrzymów odwiedzających starca, którzy naruszali ich odosobnienie, i pisali na starca donosy.

Ojciec Ferapont należał do typu „подвижников, замыкающихся в самодавлеющей внешней аскезе, в жестких и сухих, безблагодатных и безрадостных формах исповедания» [Котельников 1999, 61]. Nie patrząc jednak na niektóre negatywne momenty w życiu monasteru odzwierciedlone w powieści F. M. Dostojewski widzi w monasterskiej jedności i duchowości zbawienie społeczeństwa. Temat osobistej, moralnej odpowiedzialności łączy się w twórczości F.M. Dostojewskiego z odpowiedzialnością ogólną, a nawet ogólnoludzką. Duchowe niebezpieczeństwo upatruje się nim w bezpodstawności, w odosobnieniu i wyobcowaniu. Samotna wolność obraca się w opętanie, samowolę, które mogą doprowadzić człowieka do samozniszczenia. F.M. Dostojewski przeciwstawia temu ideał całościowego ludzkiego życia, w którym zachowane są organiczne więzi osoby z Bogiem i z otaczającym światem. $Z$ duchowo - moralnym zorganizowaniem stanu mniszego Pustelni Optyńskiej pisarz wiąże nadzieje na „нравственное перерождение человека от рабства к свободе" [Достоевский, online (page 5)].

Takim sposobem historyczno - kulturalna, literacka działalność F.M. Dostojewskiego i ofiarno - ascetyczna, moralno - duchowa działalność monasteru Kozielskiej Pustelni Optyńskiej pod wezwaniem Ofiarowania NMP jawią się przez swoje duchowe oddziaływanie ważniejszym czynnikiem twórczego procesu rozwoju prawosławnej kultury w Rosji.

\section{Zakończenie}

Żywe kontakty ze starcami z Pustelni Optyńskiej otwierały w filozofach i pisarzach pokłady głębokiej du- chowości, podtrzymujące ich siły do moralnego przeobrażenia nie tylko własnej osoby, ale i całego społeczeństwa. W swej twórczości ofiarowują współczesnemu sobie odbiorcy - czytelnikowi psychologiczno - duchowy materiał do rozmyśleń na egzystencjalne pytania: kim jestem?, po co istnieję? Dokąd zmierzam? Czym jest życie i śmierć? Twórcy wiedzę tę czerpali nie tylko z żywego obcowania z mieszkańcami Optyni. Cała struktura życia monasteru, jego literacka i gospodarcza działalność, otwartość na Boga i drugiego człowieka były traktatem, który przemawiał do Iwana Kirjewskiego, Konstantina Leontjewa i wielu, wielu innych.

Czerpane tu wzorce prawosławna inteligencja rozpowszechniła na całe społeczeństwo za pośrednictwem swej literackiej i wydawniczej działalności, kształcąc i wychowując społeczeństwo na zasadach prawosławnej moralności. Charakterystycznym jest, że badając zachodni wpływ, rosyjska kultura została stworzona na podstawie swojej prawosławnej. W większości to zasługa duchowego służenia monasteru Kozielskiej Pustelni Optyńskiej i jego wydawniczej działalności.

Po odwiedzeniu monasteru N.W. Gogol, L.N. Tołstoj, F.M. Dostojewski - ludzie różnych poglądów i różnie odnoszących się do starców - nie mogli nie zachwycać się siłą ich duchowego wpływu i dzięki temu mogli oni zjednoczyć naród i inteligencję.

Mnisi Pustelni Optyńskiej swoją moralno - duchową opieką znanych rosyjskich pisarzy i literackich działaczy tego czasu, przyczynili się do formowania narodowych charakterów autorów i ich bohaterów, podtrzymywaniu prawosławnych tradycji w literaturze. Wpływ optyńskich schimnichów na filozoficzny światopogląd I.W. Kirejewskiego, A.S. Chomiakowa, K.N. Leontjewa - pierwszych rosyjskich prawosławnych filozofów i krzewicieli oświaty, przedstawicieli słowianofilstwa i twórców Rosyjskiej idei - pojawił się w dziełach prawosławnej filozofii.

Monaster Pustelni Optyńskiej posiada ogromne znaczenie socjalno - historyczne, jako strażnik prawosławnej moralności i duchowości rosyjskiego społeczeństwa w XIX wieku. Monaster zachował historycznie ustanowione zasady Prawosławia i tradycje rosyjskiej kultury, urzeczywistnione w wyjątkowych opowiadaniach rosyjskich pisarzy XIX wieku i przez nich okazywał swój wpływ na następne pokolenia rosyjskiego społeczeństwa, rozpowszechniając swój zbawienny wpływ w całym świecie.

\section{Bibliografia}

Бердяев Н. А., 1926, Константин Леонтьев: Очерк из истории русской религиозной мыссли, Paris, [online], http:// www.odinblago.ru/filosofiya/berdyaev/berdyaev_leontev_ ocherk/6/ [05.05.2015].

Благословенная Оптина, 1997, Козельск, [online], http://www. optina.ru/history/optina/ [05.05.2015].
Буданова Н., 2005, Книги, подаренные Ф.М. Достоевскому в Оптиной Пустыне, София №1, [online], http://ricolor.org/ history/cu/lit/4/optin/ [05.05.2015].

Булгаков С. Н., 1993, Победитель Побежденный, [w:] Сочинения в двух томах, Том 2, Избранные статьи, Москва, s. 546-563. 
Воропаев В. А., 2002, Гоголь над страницами духовных книг, Москва.

Говоруха-Отрок Ю. Н. Несколько слов по поводу кончины К.Н. Леонтьева, [online], http://az.lib.ru/g/goworuhaotrok_j_n/ text_1891_leontiev.shtml [05.05.2015].

Гоголь Н. В., 2001, Духовная проза. Москва.

Гоголь Н. В., 2009, Полное собрание сочинений и писем: В 17 m., Т. 14. Москва-Киев.

Долгов К. М., 1997, Восхождение на Афон. Жизнь и миросозерияание Константина Леонтьева. Москва.

Достоевская А. Г., 1971, Воспоминания, Москва.

Достоевский Ф.М., Братья Карамазовы, [online (page 5)], http://www.klassika.ru/read.html?proza/dostoevskij/ karams.txt\&page $=5$, [online (page 6)], http://www.klassi$\mathrm{ka} . \mathrm{ru} / \mathrm{read} . \mathrm{html}$ ? proza/dostoevskij/karams.txt\&page $=6$, [05.05.15]

Каширина В., 2013, Слова подвижнические, „Православное книжное обозрение», № 8 (032), s. 60 - 75

Киреевский И. В., 1984, Избранные статьи. Москва.

Киреевский И. В., 1997, О нужде преподавания церковно-славянского языка в уездных училищах, „Литературная учеба”, № 5-6, s. 106-109.
Концевич И. М., 1995, Оптина Пустьнь и ее время. Свято-Троицкая Сергиева Лавра.

Котельников В. А., 2002, Православные подвижники и русская титература. На пути к Оптиной. Москва.

Котельников В. А., 1999, Святость, радость и творчество. Т. 3, СПб.

Леонтьев К. Н., Добрые вести, [online], http://az.lib.ru/l/leontxew_k_n/text_0440.shtml, [05.05.2015]

Леонтьев К. Н., 1914, Письмо о вере, молитве, о немощи духовенства и о самом себе, „Богословский вестник», №2, [online], http://www.bogoslov.ru/bv/text/175934/index.html, [05.05.2015].

Нилус С. Святьюня под спудом, [online], http://azbyka.ru/fiction/svyatynya-pod-spudom/,[05.05.15].

Переписка К. Н. Леонтьева с В. В. Розановым, [online], http:// dugward.ru/library/rozanov/rozanov_leontyev_perepiska. html [05.05.2015].

Толстой Л. Н., 1952, Полное собрание сочинений в 90 томах, Т. 51, Москва, 1952.

Флоровский Г., 1991, Пути русского богословия. Киев.

Фудель С. И., Собрание сочинений в трех томах, Т. 3, [online], http://predanie.ru/lib/book/174680/ [05.05.15].

Четвериков С. И., протоиер., 1988, Оптина пустынь. Париж.

Rozmiar artykułu: 1,1 arkusza wydawniczego 